\title{
JURNAL TESLA
}

\section{REDAKSI TESLA}

Pemimpin Umum

: Harto Tanujaya, S.T., M.T., Ph.D (Untar)

Dekan Fakultas Teknik Universitas Tarumanagara

Ketua Dewan Penyunting

Wakil Ketua Dewan Penyunting

Dewan Penyunting Ahli

Penyunting Pelaksana

Pelaksana Teknis

Penerbit

Alamat Penerbit
: Dr. Ir. Endah Setyaningsih, MT. (Untar)

: Yohanes Calvinus, ST. MT.

: Prof. Dr. Ir. Dali Santun Naga, MMSI. (Untar)

Prof. Dr. Ir. Indra Surjati, MT. (Usakti)

Ir. Hadian Satria Utama, MSEE. (Untar)

Dr. Ir. Eko Syamsuddin, M.Eng. (BPPT)

Didi Surian, Ph.D. (Untar)

Henry Candra, S.T., M.T., Ph.D. (Usakti)

: Joni Fat, ST. ME.

Drs. F.X. Sigit Wijono, MT.

Suraidi, ST. MT.

Meirista Wulandari, ST. M.Eng.

Yohanes Calvinus, ST.MT

: Sofyan Maulana A.Md. Kom

: Program Studi Teknik Elektro

Jurusan Teknologi Industri

Fakultas Teknik

Universitas Tarumanagara

: Jln. Letjen. S. Parman No. 1

Jakarta - 11440

Telp : 021-5638359, 5672548

Fax : 021-5663277

Email : tesla@ft.untar.ac.id

Web : https://journal.untar.ac.id/index.php/tesla/index

Nama "TESLA" diambil dari nama tokoh seorang ilmuwan listrik yang diabadikan menjadi satuan medan magnetik yaitu NIKOLA TESLA, yang lahir di Kroasia. Jurnal TESLA merupakan Jurnal Ilmiah Teknik Elektro yang diterbitkan 2 kali dalam setahun, yaitu pada bulan Maret dan Oktober. Sejak Bulan Oktober 2009, Jurnal TESLA telah menjalin kerjasama dengan Indonesian Experts Electronics - Jakarta (IEE-J) yang mempunyai visi dan misi dalam meningkatkan Jurnal Teknik Elektro menjadi berkualitas. 